81 (1929); 3) Chen, K.K., Wu, C.K. A.nd Henriksen, E.: Proc. Soc. exp. Biol. Med. 26, 348

(1928); 4) PATIL, P.N., TYe, A. ANd LaPidus, J.B.: J. Pharmacol. exp. Ther. 148, 158 (1965)

\title{
EFFECTS OF FASTING ON THE HENLE'S LOOP FUNCTION OF RAT KIDNEY
}

\author{
Yoshimichi MURAYAMA* and Fuminori SAKAI \\ Department of Pharmacology, Faculty of Medicine, University of Tokyo, \\ Bunkyo-ku, Tokyo, Japan
}

Accepted April 2, 1975

It is generally known that sodium excretion into the urine increases for several days when a normal person fasts completely. While this phenomenon has been the subject of numerous investigations (1-5), the mechanism of urinary losses of sodium and the location in the nephron where it occurs are obscure. Some authors $(2,5)$, however, have suggested a localization of the phenomenon to be Henle's loop and distal tubules by clearance experiments. Therefore, the present experiments were performed to clarify the changing of the function of the Henle's loop of the fasted rat kidney using the single nephron perfusion technique.

Male Wistar rats weighing $150-260 \mathrm{~g}$ were used in the experiments. Rats of the control non-fasted group were given free access to a dry pellet diet $(\mathrm{Na} 84 \mathrm{mEq} / \mathrm{kg}, \mathrm{K} 110 \mathrm{mEq} /$ $\mathrm{kg}$ ) just prior to experiment and those of the fasted group were deprived of food 18 to $24 \mathrm{hr}$ prior to experimental procedures. All rats were given tap water.

The animals were anesthetized with Nembutal $(50 \mathrm{mg} / \mathrm{kg}$, Abbott) i.p. and placed on a heated table. After tracheotomy, the fcmoral vein and the left ureter were catheterized, and the left kidney was exposed. During these surgical procedures, $1 \mathrm{ml}$ of Ringer's solution was infused intravenously to replace surgical losses.

The loop of Henle was perfused according to the method of Cortney et al. (6) as previously described $(7,8)$. The proximal tubular segment was filled with colored oil to stop the flowing of glomerular filtrate, and the perfusion pipette was inserted into the late proximal tubule in order to perfuse the single nephron. One percent $\mathrm{NaCl}$ solution colored with $0.05 \%$ lissamine green was used as perfusate and the perfusion rate was $19 \mathrm{nl} / \mathrm{min}$. A collection was made from the early segment of the distal tubule of the same nephron.

Left ureteral urine was collected at appropriate intervals for 2 to $4 \mathrm{hr}$. Blood samples were collected by heart puncture after the experiment.

The osmolarities of the tubular samples and ureteral urine were estimated with a microosmometer. The sodium concentration of the tubular fluid was determined with an ultramicro-flamephotometer (Erma, Model 677), the sodium and potassium concentrations in

\footnotetext{
* Present address: Department of Pharmacology, Kawasaki University School of Medicine,
} Kurashiki, Japan 
serum and urine with a flamephotometer (Evans, Model A), and urea concentration by the phenol-hypochlorite method using Conway's microdiffusion apparatus.

The results of experiments are summarized in Table 1. The mean ratio of osmolarity of perfused tubular fluid to plasma, $(\mathrm{TF} / \mathrm{Pl})_{o \text { sm }}$ was significantly elevated from a value of 0.52 in non-fasted rats to 0.63 in fasted, and the mean $(\mathrm{TF} / \mathrm{Pl})_{\mathrm{Na}}$ was also elevated in parallel with the osmolarity ratio, from 0.44 to 0.54 . The sodium concentrations and osmolarities in plasma of the both groups were almost the same. From these results, it is assumed that sodium reabsorption in ascending limb of Henle`s loop was depressed by fasting.

TABLE 1. Effects of fasting on the osmolarity and sodium concentration of the distal tubular fluid and ureteral urine in single short nephron microperfusion experiments.

\begin{tabular}{|c|c|c|c|c|c|c|c|c|}
\hline & \multirow{2}{*}{$\begin{array}{c}\text { No. } \\
\text { of } \\
\text { rats }\end{array}$} & \multirow[b]{2}{*}{$\stackrel{\text { osm }}{(\mathrm{mOsMol} / 1)}$} & \multicolumn{3}{|c|}{ Distal urine } & \multicolumn{3}{|c|}{ Ureteral urine } \\
\hline & & & $\underset{(\mathrm{mEq} / \mathrm{l})}{\mathrm{Na}}$ & $(\mathrm{TF} / \mathrm{P} 1)_{0 \leqslant \mathrm{~m}}$ & $(\mathrm{TF} / \mathrm{P} 1)_{\mathrm{Ka}}$ & $\underset{\text { (OsMol } 1)}{\text { osm }}$ & $\begin{array}{l}\mathrm{Na} \\
\text { (mEa/ }\end{array}$ & (1) \\
\hline Non-fasting & 5 & $\begin{array}{l}161 \\
\therefore 10.9 \\
(15)\end{array}$ & $\begin{array}{r}63.8 \\
+5.0 \\
(12)\end{array}$ & $\begin{aligned} & 0.52 \\
= & 0.04\end{aligned}$ & $\begin{array}{r}0.44 \\
\pm 0.04\end{array}$ & $\begin{array}{r}2.08 \\
\pm 0.12\end{array}$ & $\begin{array}{r}64.1 \\
\therefore \quad 18.8\end{array}$ & $\begin{array}{r}316 \\
++48\end{array}$ \\
\hline Fasting & 4 & $\begin{array}{l}194^{*} \\
\pm 10.9 \\
(16)\end{array}$ & $\begin{array}{c}83.5^{*} \\
\pm 2.4 \\
(11)\end{array}$ & $\begin{array}{c}0.63^{*} \\
\pm 0.04\end{array}$ & $\begin{array}{r}0.54 \\
\pm 0.05\end{array}$ & $\begin{aligned} & 1.29^{* *} \\
= & 0.08\end{aligned}$ & $\begin{array}{r}43.9 \\
+4.2\end{array}$ & $\begin{array}{r}182 \\
\pm 18\end{array}$ \\
\hline
\end{tabular}

The numbers of the punctured sample are given in parentheses.

The data of ureteral urine osmorality and electrolyte are the mean values of the samples which were collected during puncture procedures.

$(\mathrm{TF} / \mathrm{Pl})$ indicates tubular fluid/plasma ratio.

$*$ means significantly different from non-fasted rats $\mathrm{p}<0.05$.

$* * p<0.001$.

Ureteral urine osmolarity and electrolyte concentration appeared to decrease by fasting as shown in Table 1. Therefore, further experiments were performed to determine the corticomedullary concentration gradients of electrolyte and urea in additional rats under conditions similar to those pertaining during the microperfusion experiments. The results are presented in Table 2. Urea concentration and total calculated osmolarity in tissue of fasted rat kidney were lowered as compared to the non-fasted rats. In fasted rats, the urine osmolarity and potassium concentration were significantly decreased and the urine flow was markedly increased without significant change in the sodium concentration. Consequently, the sodium excretion in fasted rats increased more than that of normal rats.

From these results, it is suggested that in fasted animals, water reabsorption in the collecting duct decreases due to lowering of tissue osmolarity caused by decreased sodium reabsorption of Henle's loop and possibly by decreased urea trapping in medulla. The mechanism of the inhibition of sodium reabsorption in Henle's loop in fasted rat is now under further study.

To summarize, fasting for 18 to 24 hr causes elevations of TF/Pl ratio of osnolarity 
TABLE 2. Effects of fasting on the gradients of osmolarity, electrolyte and urea concentration in tissue slices of rat kidney.

\begin{tabular}{|c|c|c|c|c|c|c|}
\hline & & & \multicolumn{2}{|c|}{ Non-fasting } & \multicolumn{2}{|c|}{ Fasting } \\
\hline & No. of rats & & 4 & & 4 & \\
\hline & $\mathrm{Na}$ concentration & I.M. & 309 & \pm 14.0 & 280 & $=62.1$ \\
\hline & (mEq/L. tissue water) & $\mathrm{O} . \mathrm{M}$ & 150 & $+\quad 5.2$ & 131 & \pm 10.3 \\
\hline & & Cortex & 67.5 & \pm 2.49 & 58.5 & \pm 8.32 \\
\hline \multirow{9}{*}{$\begin{array}{l}\text { Tissue } \\
\text { slices }\end{array}$} & Urea concentration & 1.M. & 899 & 197.2 & $551^{*}$ & $J=88.8$ \\
\hline & (mMol/l. tissue water) & O.M. & 238 & $\doteq 19.9$ & 185 & ta. 19.3 \\
\hline & & Cortex & 42.6 & \pm 4.24 & 32.9 & $\pm \quad 1.73$ \\
\hline & Total osmolarity & I.M. & 1659 & $\div 126$ & 1235 & \pm 124 \\
\hline & (mOsm/l. tissue water) & O.M. & 683 & $=27.5$ & 579 & \pm 36.3 \\
\hline & & Cortex & 323 & $\div \quad 4.8$ & $278^{* * *}$ & $\pm \quad 3.2$ \\
\hline & Water content & I.M. & 84.1 & $\pm \quad 4.43$ & 90.2 & $\pm \quad 1.09$ \\
\hline & $(\%)$ & O.M. & 83.1 & $\therefore \quad 1.92$ & 84.6 & \pm 0.58 \\
\hline & & Cortex & 76.1 & \pm 0.82 & 77.7 & \pm 0.60 \\
\hline \multirow{4}{*}{ Urine } & Osmolarity (mOsmil) & & 2272 & $=153$ & $1456^{*}$ & \pm 246 \\
\hline & Na concentration $(\mathrm{mEq} / \mathrm{l})$ & & 48.6 & \pm 13.7 & 32.3 & $\pm \quad 3.68$ \\
\hline & $\mathrm{K}$ concentration $(\mathrm{mEq} / 1)$ & & 324 & $\perp 39.1$ & $117^{* * *}$ & \pm 32.6 \\
\hline & Flow $(\mu l:$ min $)$ & & 0.48 & \pm 0.038 & $1.98^{* *}$ & \pm 0.45 \\
\hline \multirow{3}{*}{ Serum } & $\mathrm{Na}$ concentration (mEq/) & & 139 & $\pm \quad 2.96$ & 139 & $\doteq=0.85$ \\
\hline & $\mathrm{K}$ concentration $(\mathrm{mEq} / \mathrm{l})$ & & 5.89 & \pm 0.60 & 5.37 & $\therefore \quad 0.14$ \\
\hline & Urea concentration ( $\mathrm{mMol} / \mathrm{l})$ & & 10.8 & \pm 1.76 & 7.76 & $\doteq 1.51$ \\
\hline
\end{tabular}

I.M.; inner medulla + papilla, O.M.; outer medulla,

$* \mathrm{p}<0.05, \quad * * \mathrm{p}<0.02, \quad * * * \mathrm{p}<0.01, \quad \pm$ s.e.

and sodium concentration in early distal segments. Natriuresis by fasting may be partially due to a decreased sodium reabsorption in the ascending limb of the Henle's loop.

\section{REFERENCES}

1) Chinn, R.H., Brown, J.J., Fraser, R., Heron, S.M., Lever, A.F., Murchison, L. and Robertson, J.I.S.: Clin. Sci. 39, 437 (1970); 2) HoffMan, R.S., MARInNo, J.A., WAHL, G. AND Arky, R.A.: J. Lah. clin. Med. 74, 915 (1969); 3) Garnett, E.S., Cohen, H., Hahmias, C. and Viol, G.: Metabolism 22, 867 (1973); 4) Schloeder, F.X. And Stinebaugh: Metabolism 19, 1119 (1970); 5) Wrigirt, H.K., Gann, D.S. and Albertsen, K.: Metabolism 12, 804 (1963); 6) Cortney, M.A., Nagel, W. and Thurau, K.: Pflügers Arch. 287, 286 (1966); 7) Murayama, Y., Suzuki, A., Tadocoro, M. and Sakai, F.: Japan. J. Pharmacol. 18, 518 (1968); 8) Sakai, F. AND Murayama, Y.: Japan. J. Pharmacol. 21, 23 (1971) 